\title{
АРХЕОЛОГИЧЕСКИЕ РАСКОПКИ ГОРОДИЩА РАХАТ В ПОЛЕВОМ СЕЗОНЕ 2019 г.
}

\author{
(C) 2020 г. Т. Ж. Тулегенов, А. Г. Чекин, Ж. Құрбанәлі
}

\begin{abstract}
Археологический комплекс Рахат - уникальное место, где на небольшом пространстве мы можем проследить историю региона с эпохи камня (найдена стоянка верхнего палеолита) до этнографического периода (мельницы и землянки XIX в.) Комплекс расположен на надпойменных террасах у выхода реки из ущелья Рахат и состоит из: поселения Орикты, могильников Рахат-I-II, городища Рахат и одноименной палеолитической стоянки. В статье изложены некоторые результаты полевых исследований 2019 г., проводившихся на городище Рахат. Изучение памятника дает более полное представление о быте и хозяйстве средневекового города в Иссыкском микрорегионе. В ходе исследования получен обширный керамический материал. Археологические раскопки, произведенные заповедником-музеем «Иссык», дали возможность подтвердить хронологические рамки существования городища Рахат, высказанные академиком К. М. Байпаковым.

Ключевые слова: археология, Жетысу, заповедник-музей «Иссык», ассоциация «Алтын адам», городище Рахат, керамика, средневековье, раскопки, археологическая разведка, стратиграфия, культурный слой
\end{abstract}

\section{Введение}

В 1999 году в ходе археологических исследований на курганах могильника Иссык участники археологоэтнологической комплексной экспедиции университета «Кайнар» и ассоциации «Алтын адам» обратили внимание на холмы, расположенные на окраинах поселка Рахат. Было высказано предположение об искусственном их характере возникновения, что было подтверждено рассказами местных жителей о многочисленных находках в виде фрагментов керамических изделий, сделанных на территории предполагаемого городища. Для подтверждения или опровержения гипотезы была снаряжена кратковременная разведывательная экспедиция под руководством археолога Б. Н. Нурмуханбетова.

В ходе разведки подтвердился искусственный характер холмов. С большой долей вероятности стало ясно, что это городище, которое представляет собой комплекс разнохарактерных и разновременных сооружений, тянется вдоль предгорий с южной части сел Орикти (бывш. Красный Восток) и Рахат (Енбекшиказахский

Работа выполнена при финансовой поддержке Министерства культуры и спорта РК, ИРН проекта BR06449571 
p-н, Алматинская обл.). Наиболее значительная часть городища находится у села Рахат, с правой стороны у входа в ущелье Тасмурын. О разновременности и преемственности городища «Рахат» можно судить по подъемной керамике. Ее хронология прослеживается от сако-усуньского времени до средневековья.

В 2004 г. на городище Рахат сотрудниками Института археологии им. А. Х. Маргулана проводились работы разведывательного характера. Закладка шурфа размерами $4 \times 4$ м на поверхности центрального бугра городища Рахат выявила культурный слой толщиной около 70 см, содержащий золу, кости и фрагменты сосудов. На поверхности центрального холма и на близлежащей территории была собрана коллекция керамики, среди которой обломки типично сакоусуньской посуды, фрагменты котлов, кувшинов, хумов, а также средневековая керамика. На основе выявленных находок был сделан вывод о длительном периоде существования поселения, первый этап которого связан с эпохой раннего железа [Байпаков, 2008, c. 71-72].

В 2013 г. территория городища вошла в охранную зону Государственного историко-культурного заповедника-музея «Иссык» (созданного в 2010 г.). С этого момента заповедник-музей «Иссык» начинает планомерное археологическое исследование примыкающего к городищу ущелья Рахат. К 2015 г., благодаря разведочным работам, было выяснено, что археологический комплекс ущелья Рахат, расположенный вдоль поймы одноименной реки, включает в себя памятники, относящиеся к разному времени - от эпохи палеолита до средневековья.
В 2017 г. исследование городища Рахат было продолжено археологами заповедника-музея «Иссык» совместно со специалистами из КНР (Институт археологии провинции Шаньси) закладкой разведочной стратиграфической траншеи. Разведочные раскопы были заложены в двух местах - в северо-восточной и югозападных частях вала. Стратиграфический шурф, размерами $10 \times 2 \times 4$ м, заложен в юго-западной части, у подножья центральной возвышенности. После снятия дернового слоя и зачистки на различных глубинах раскопа в огромном количестве были выявлены фрагменты керамики (венчики, донца и стенки сосудов), а также по всей площади раскопа встречены кости крупных и мелких домашних животных. Срез был доведен до уровня 4 м, где нижние слои прослежены до стерильного слоя светло-коричневого суглинка. В разрезе четко выделяется девять культурных слоев, из них четыре - пятна золистой глины красноватого цвета. Находки представлены фрагментами керамики, изделиями из бронзы, камня и кости (оберег).

Собранные на городище фрагменты керамики различаются по форме венчиков и тулова, способу изготовления и по функциональному назначению. Хронологические рамки материала охватывают период от эпохи раннего железа до Средневековья. Найденная в одной из разведывательных ям печь для обжига керамики подтвердила предположение об искусственном происхождении холмов. Стало ясно, что необходимо продолжить исследования, расширить площадь раскопа для получения материала и выявления более ранних культурных слоев [Мухтарова и др., $2018]$. 
Тулегенов Т.Ж., Чекин А.Г., Құрбандлі Ж. Археологические раскопки городища Рахат...

Полевые работы 2018 г. велись в двух направлениях. Первое - исследование тюркских захоронений в южной части городища, где было раскопано несколько курганных захоронений. В четырех погребениях были обнаружены костные останки четырех человек и двух лошадей, а также фрагменты конских сбруй в большом количестве. Второе направление полевых работ - выявление стратиграфии (планиграфии) центральной цитадели городища путем закладки шурфа длиной 10 м, шириной 5 м. Здесь были обнаружены фрагменты керамики и костные останки животных. В ходе работ предполагалось определить ход будущих широкомасштабных раскопок в ближайшие годы, которые, возможно, позволят открыть новый яркий памятник городской культуры Жетысу.

В 2019 г. заповедник-музей Иссык начал полевые археологические работы на городище Рахат в рамках научного проекта «Семиозис* материальной культуры Жетысу на материалах археологического комплекса Рахат с эпохи саков до XIII в.»

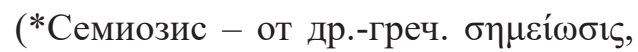
«обозначение» - термин, принятый в семиотике; обозначает процесс интерпретации знака, или процесс порождения значения).

\section{Описание материала}

Городище представляет собой восемь земляных холмов (рис. 1), центральная возвышенность, прямоугольная в плане, имеет размеры $70 \times 75$ м, высоту 20-25 м. Три холма округлой формы, вокруг них расположено пять земляных валов вытянутых пропорций. Отснят ортофотоплан городища Рахат (рис. 2) и сделаны графические разрезы с применением новейших технологий (рис. 3 ; 4).
На первом этапе исследований для выявления культурного слоя на земляном валу с южной стороны городища был заложен стратиграфический шурф размерами $5 \times 16$ м по оси С-Ю (рис. 5). Были оставлены две бровки шириной 0,5 м по оси В-3. Таким образом, шурф имел общую площадь 75 кв. м (три квадрата $5 \times 5$ м). После удаления дернового слоя 0,4 м в квадратах № 1, 2 (нумерация с севера на юг) было выявлено большое количество фрагментов керамики (венчики, стенки и донца сосудов). Во втором квадрате обнаружены две печи тандырного типа (рис. 6). Стало очевидно наличие поселенческой инфраструктуры. Было принято решение о расширении площади раскопок на запад и прирезке еще шести квадратов площадью $5 \times 5$ м. Таким образом, общая площадь составила 256 кв. м (рис. 7), произведена зачистка на глубину $0,5-0,7$ м, объем изъятого грунта составил 170 куб. м. После изучения южных и северных «бровок» они были разобраны, объем изъятого грунта составил 15 куб. м.

Вместе с керамикой на глубине 0,3-0,4 м по всей площади раскопа были выявлены кости крупных и мелких домашних животных. Далее проходил слой коричневой глины. На глубине 0,5 м - слой коричневой материковой глины. На этом уровне были выявлены ямы хозяйственного назначения, в количестве 24. На данный момент исследовано 12 из них. Все они имеют округлую форму и почти одинаковые размеры и глубину. В ходе полевых работ было выявлено около 400 фрагментов керамики, два металлических предмета (ножи), 259 элементов остеологического материала (кости животных). 


\section{ҚАЗАҚСТАН АРХЕОЛОГИЯСЫ № 2 (8) 2020}

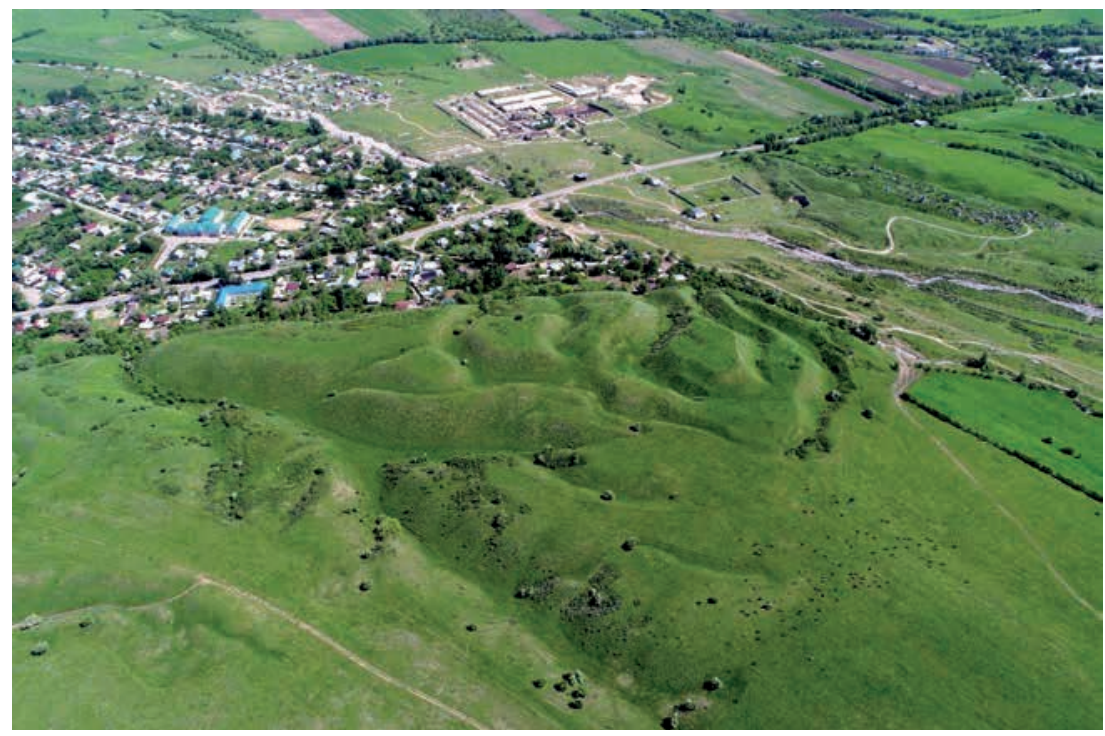

Рис. 1. Общий вид памятника до начала раскопок

Fig. 1. General view of the monument before the excavation

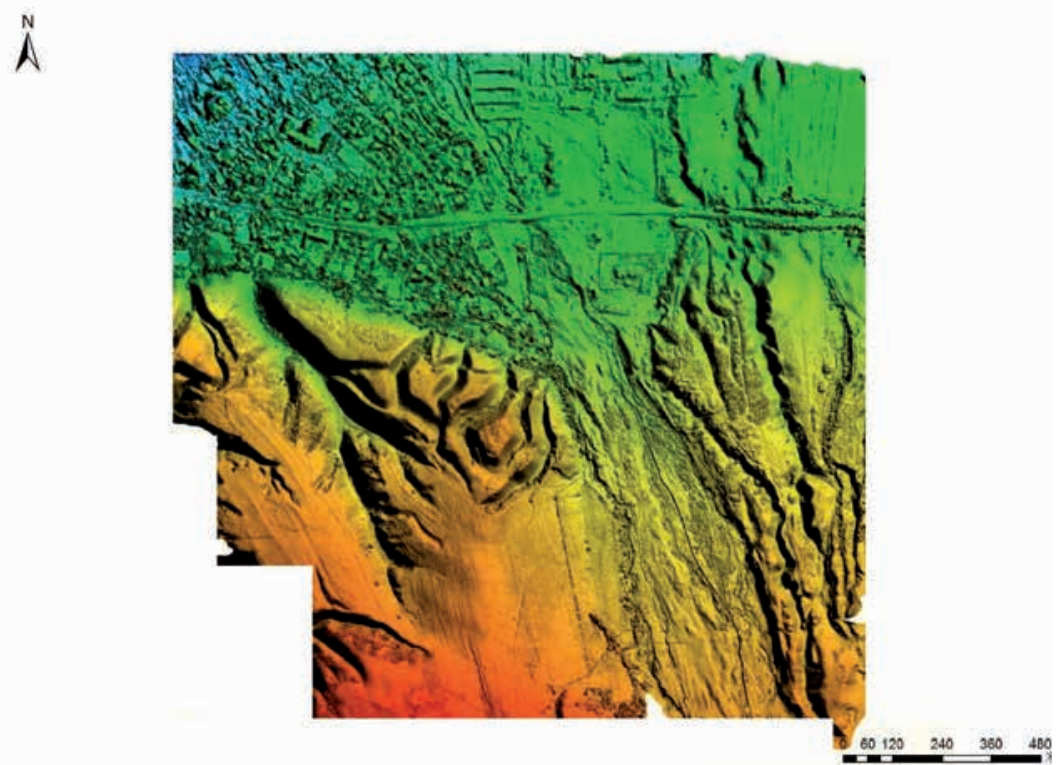

Рис. 2. Ортофотоплан археологического комплекса Рахат (ККРАЭ-2017)

Fig. 2. Orthophotomap of the archaeological complex of Rakhat (KCRAE-2017) работ:

Подробное описание полевых

Квадрат № 1. После зачистки пола раскопа, на глубине 0,7 м, выявлено несколько пятен, три из них имеют отчетливо округлую форму. Все они имели окантовку из глины отличного от материкового цвета шириной 1,5-2 см. Хозяйственные ямы (далее по тексту - яма) нумеруются 
Тулегенов Т.Ж., Чекин А.Г., Құрбандлі Ж. Археологические раскопки городища Рахат...

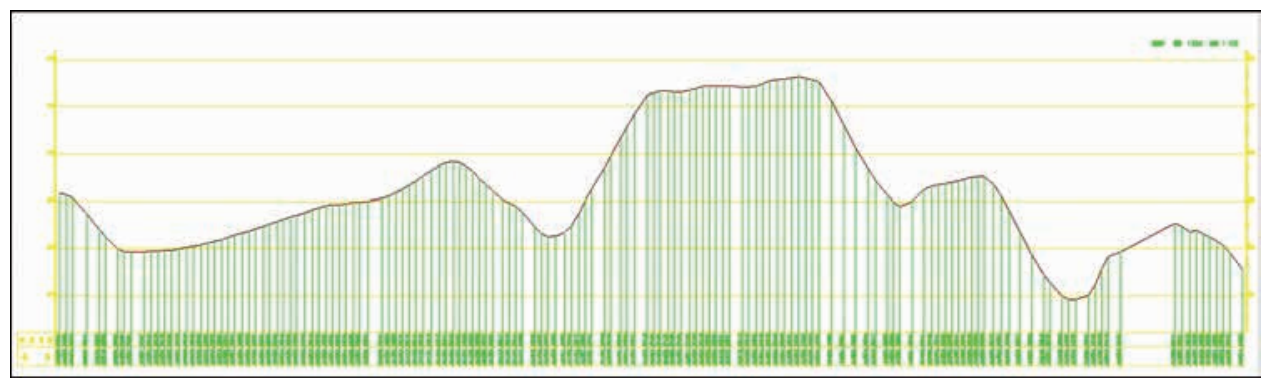

Рис. 3. Профиль разреза по направлению 3-В (ККРАЭ-2017)

Fig. 3. Section profile in the direction W-E (KCRAE-2017)

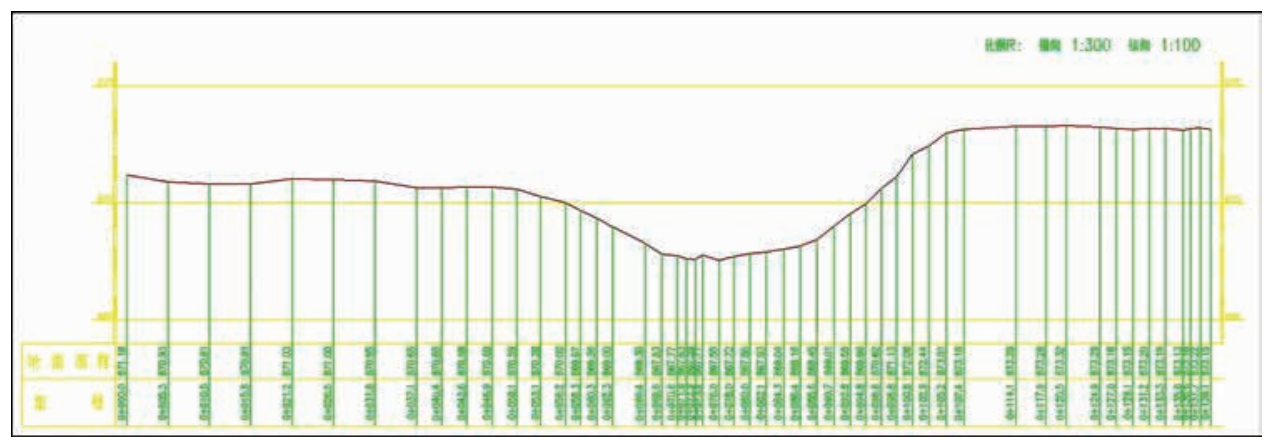

Рис. 4. Профиль разреза по направлению Ю-С (ККРАЭ-2017)

Fig. 4. Section profile in the direction $S-N(K C R A E-2017)$

с запада на восток и по принадлежности к квадрату. Яма № 1 имела заполнение светло-серого цвета с включениями фрагментов керамики, кости и обожжённой глины кирпичного цвета. Диаметр составил 0,9 м, приблизительная глубина от древней поверхности 0,7 м. Яма № 2 имела заполнение подобного цвета и большое количество костных фрагментов животных при аналогичных размерах. Яма № 3 имела разрушенные края, возможно, поэтому имела большой диаметр - 1 м.

Вещевой материал ям (погребов?) представлен большим количеством фрагментов керамики: столовой (рукояти казанов - 6 шт. и их венчики -8 шт.) и кухонной. Всего 45 элементов. Керамика фрагментированная, возможно, это объясняется стихийным характером прекращения существования городища (война, нашествие). Избыточное для одного домохозяйства количество казанов говорит о том, что город имел и гостиничную инфраструктуру.

Остеологический материал представлен фрагментами костей животных крупного и мелкого рогатого скота - 32 фрагмента (челюсти, конечности, лопатки животных).

Квадрат № 2. На глубине 0,30,4 м от поверхности земли в северозападном углу обнаружены две печи округлой формы, размеры печей составили: высота около 0,3 м, периметр в обхвате 1,9 м. На глубине 0,7 м выявлено пять пятен округлой формы и одно продолговатой овальной формы размерами $3,7 \times 0,8$ м, имеющее ориентацию ЮВ-СВ. Средний диа- 


\section{ҚАЗАҚСТАН АРХЕОЛОГИЯСЫ № 2 (8) 2020}

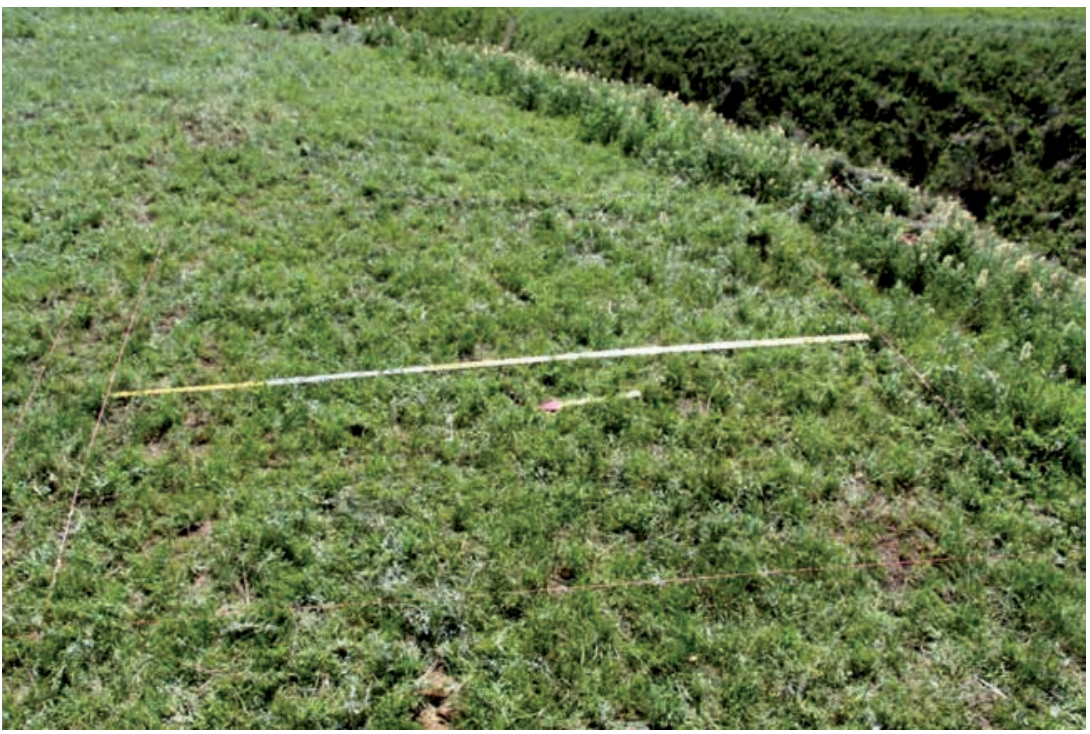

Рис. 5. Разметка раскопа

Fig. 5. Excavation marking

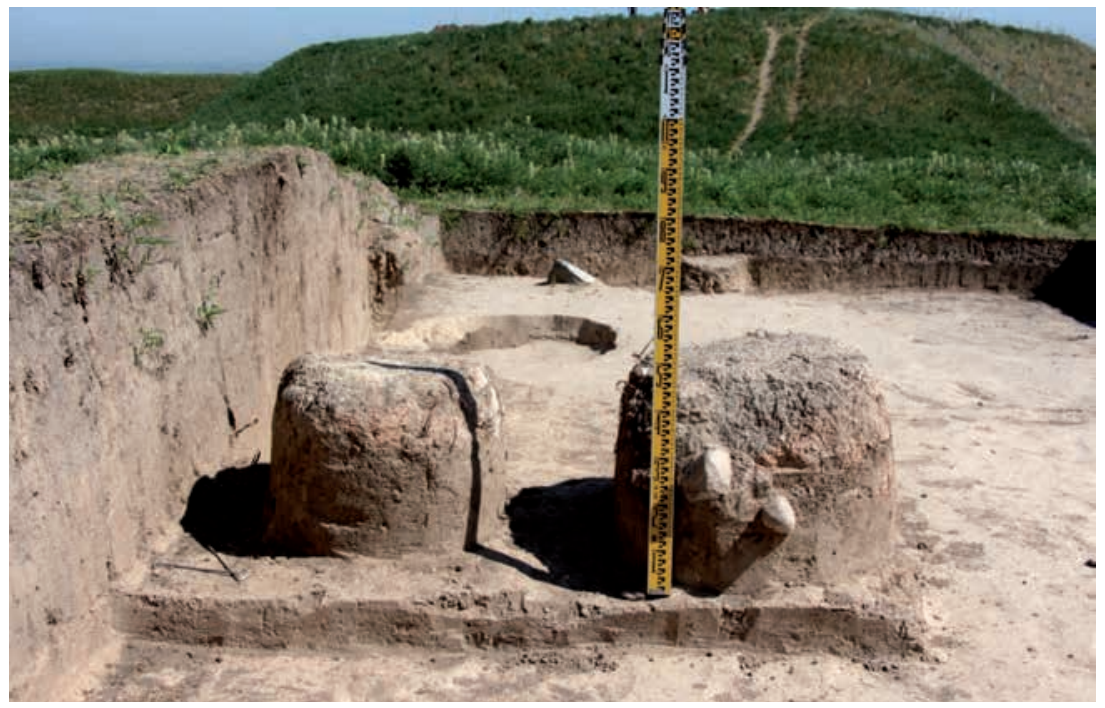

Рис. 6. Две печи тандырного типа. Стратиграфический шурф, квадрат № 2

Fig. 6. Two tandoor type furnaces. Stratigraphic pit square № 2

метр хозяйственных ям $0,9-1,1$ м. На западной стенке бровки прослеживается глина светлого цвета, возможно, это следы отвала из хозяйственных ям. Вещевой материал представлен фрагментами казанов и столовой посуды, всего 38 шт. Наибольший инте- рес представляет венчик водоноса с рукоятью.

Квадрат № 3. Исследованы две хозяйственные ямы. Юго-западная яма № 1 имела диаметр 1 м, а северозападная яма № 2 имела диаметр 0,9 м, в заполнении обнаружены фрагменты керамики и камень. 
Тулегенов Т.Ж., Чекин А.Г., Құрбандлі Ж. Археологические раскопки городища Рахат...

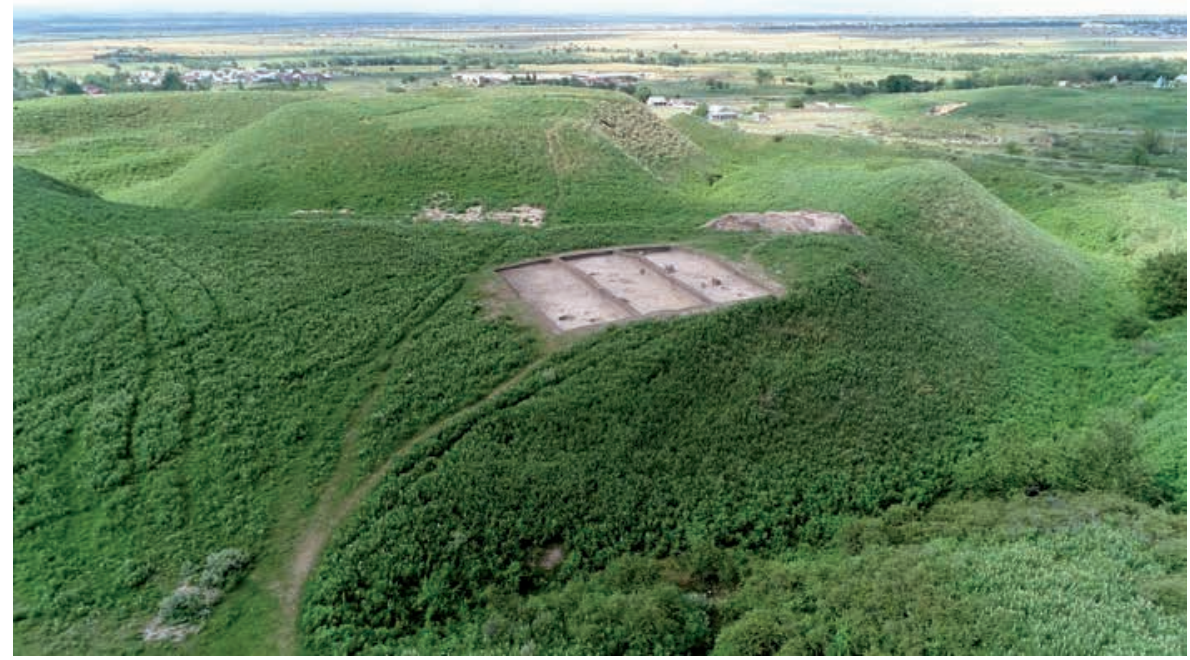

Рис. 7. Общая площады исследований на городище Рахат

Fig. 7. The total area of research on the fortress Rakhat

Вещевой материал представлен керамикой (мелкие фрагменты) и остатками дерева, вертикально уходящего в землю (возможно, опора под крышу здания).

В квадрате № 4 выявлены две ямы, уходящие под восточную и южную бровки, заполнение светлосерого цвета. Яма № 1 диаметром 1,1 м. Яма № 2 диаметром 0,95 м. Вещевой материал примерно аналогичен - элементы столовой и кухонной посуды. Научную значимость имеют только два осколка казана, найденные в северо-восточном углу. Фрагменты дают представление о венчике, тулове и дне сосуда.

Квадрат № 5. Обнаружено пять хозяйственных ям округлой формы. Яма № 1 имела диаметр 1 м, № 2 0,9 м, № 3 - 1 м, № $4-0,6$ м, № 5 - 1,3 м. Исследованы две ямы № 4 и № 5. На дне ямы № 4 найдены фрагменты хума - стенки сосуда (рис. 8), другие части (венчик, тулово) были найдены на уровне древней поверхности, что подтверждает версию о внезапном заполнении ям-погребов. Яма № 4 - самая большая из обна- руженных. Возможно, имела более позднее происхождение, так как имела отличное от других заполнение коричневого цвета и не имела включений керамики и костей (рис. 9), а также вплотную примыкала к яме № 3, частично задев ее стенки, имея при этом самую большую глубину 0,9 м от древней поверхности.

Вещевой материал представлен казаном без ручек, кружкой, светильником с петлевидной ручкой. Все предметы найдены в юго-западном углу квадрата и являются датирующим материалом.

Квадрат № 6. Выявлено шесть хозяйственных ям, пять из которых имели примерно одинаковые размеры в диаметре - 0,9-1 м. Яма № 5 имела в результате обрушения грушевидную в горизонтальном сечении форму и больший диаметр 1,2 м. Исследованная яма № 2 материала не дала.

Вещевой материал представлен большим количеством осколков хума (фрагменты венчика и стенок сосуда).

Квадрат № 7. Выявлено пять ям-погребов, четыре из них исследо- 
вано. Яма № 1 диаметром 1,1 м, глубиной 0,8 м; заполнение из перемеса глины желтого и молочного оттенков. Яма № 2 глубина 0,6-0,7 м от древней поверхности, диаметр 0,7 м. Яма № 3 диаметром 1,1 м, глубиной 0,8 м; в за- полнении имела фрагменты керамики - три рукояти от котлов. В заполнении погреба № 4 выявлен венчик от котла, другая часть которого найдена на предполагаемом полу здания в 2 м от ямы, что подтверждает гипотезу о

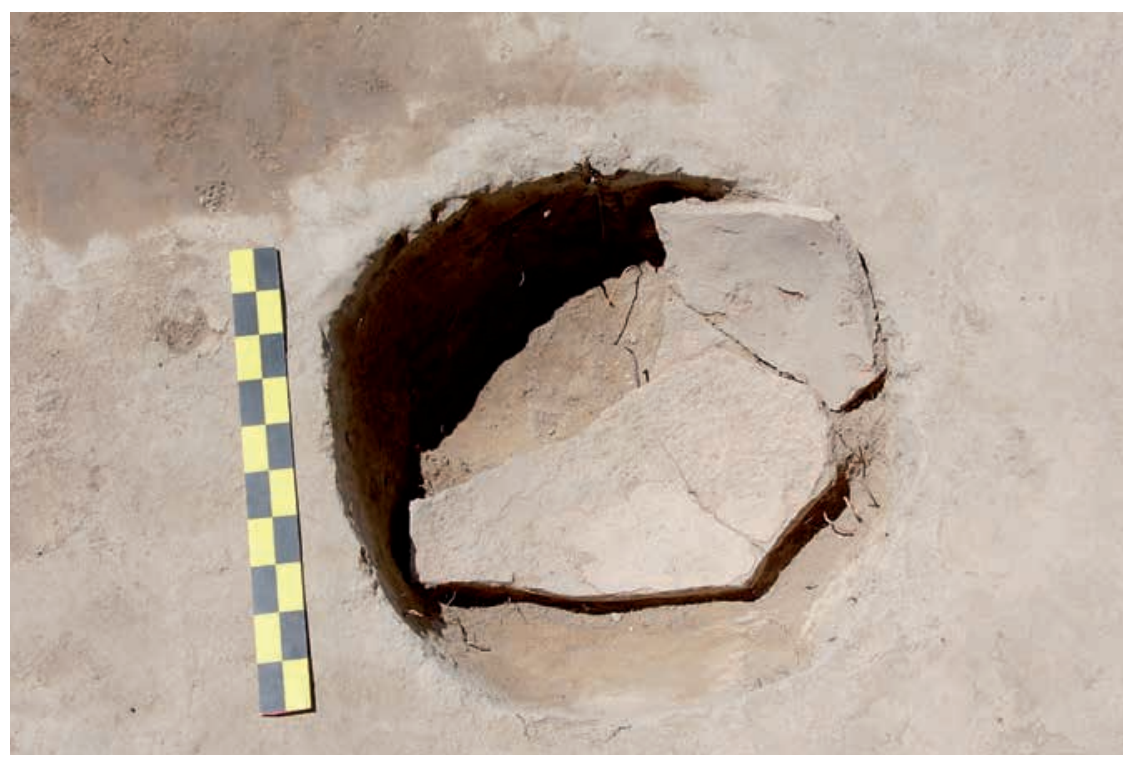

Рис. 8. Фрагменты хума. Квадрат № 5, яма № 4. Фото авторов

Fig. 8. Fragments of hum. Square № 5, pit № 4. Authors's photo

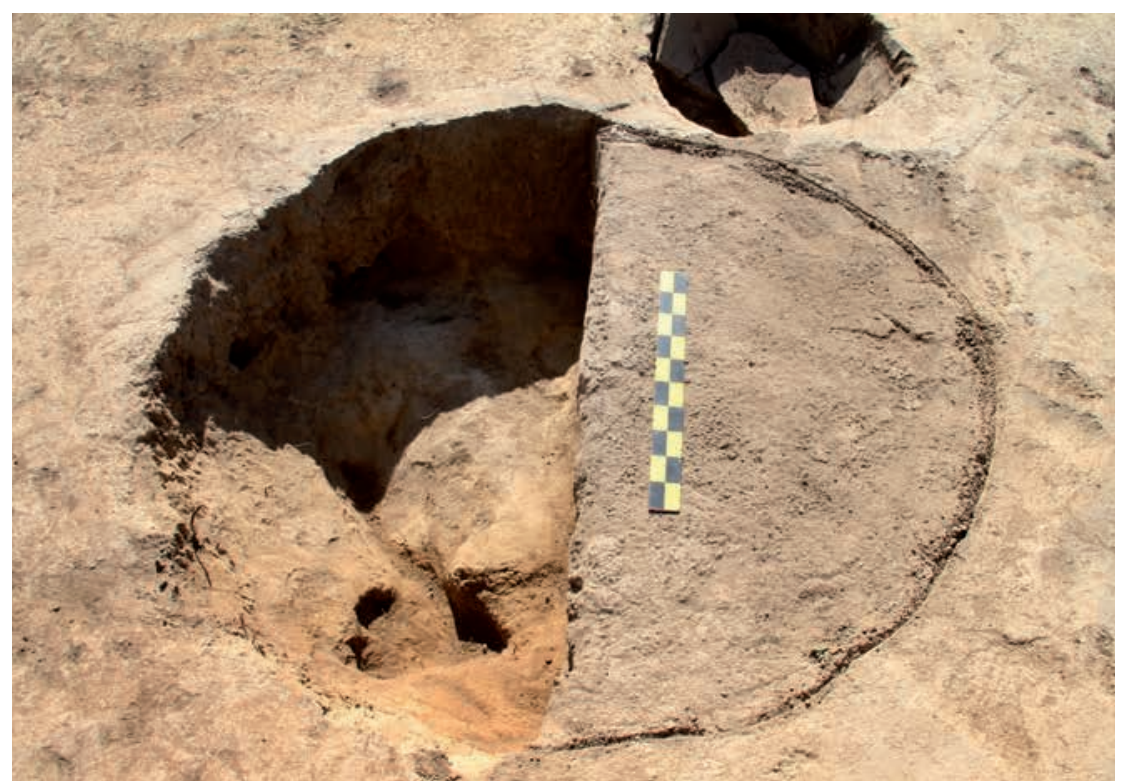

Рис. 9. Квадрат № 5, яма № 4. Фото авторов

Fig. 9. Square № 5, pit № 4. Authors's photo 
Тулегенов Т.Ж., Чекин А.Г., Құрбандлі Ж. Археологические раскопки городища Рахат...

том, что часть ям была пуста на момент разрушения. Яма № 5 уходит под восточную бровку в разрезе прослеживаются кости животных.

Вещевой материал представлен фрагментами керамики, рукоятями котлов, венчиком котла, костями животных.

Квадрат № 8. Две хозяйственные ямы - № 1 и 2 примерно одного диаметра - 1,1 м.

Квадрат № 9. Одна хозяйственная яма.

В квадратах № 1 (южная стена), № 4 (западная стена), № 6 (западная стена), № 7 (южная стена) были отобраны образцы на споропыльцевой и карпологический анализы и направлены в Институт геологических наук им. К. И. Сатпаева (г. Алматы).

С целью сохранения памятника на городище Рахат были проведены работы по консервации и рекультивации. Подразумевая возможное наличие более древних слоев, исследованные площади на городище были законсервированы для дальнейшего изучения. С целью предотвращения разрушения стратиграфических бровок и постороннего вмешательства вся площадь раскопа на городище была засыпана грунтом отвала с применением спецтехники и рабочих.

\section{Обсуждение материала}

По результатам исследовательских работ можно отметить, что разнообразие керамики на данном городище говорит о его долговременном существовании [Байпаков, 2008, c. 71-72], среди них встречаются фрагменты кувшинообразных, котловидных, горшковидных, баночных сосудов, а также мисок (рис. 10). Наиболее характерной деталью котловидных сосудов являются налепные ручки. Среди фрагментов встречаются в основном венчики округлой формы. Фрагменты дна сосудов сакского времени, как правило, округлой формы. Также фиксируются фрагменты орнаментированной посуды. В основном встречаются каннелюры под венчиком и по шейке сосудов и ряды вдавлений округлой формы и ногтевых вдавлений, а также резной орнамент в виде косых треугольников и волнообразный орнамент.

Всего было обнаружено около 400 фрагментов керамики, которые относятся к средневековому периоду. Таким образом, это самый значительный материал для культурнохронологической атрибуции различных слоев памятника. Керамика городища представлена фрагментами сосудов, восстановить формы которых полностью не удалось.

Обилие ям, из которых большая часть примерно одного размера, наводит на мысль, что часть из них использовалась как временное зернохранилище и, возможно, (имея одинаковый объем) как мера количества зерна. В целом, подтвердилась датировка городища VIII-X вв., данная К. М. Байпаковым в отчете за 2004 г. [Отчет..., 2004, л. 5].

Анализ найденных изделий из керамики и металла позволил отнести этот объект к раннему и развитому средневековью. Создание огромной империи тюрков не могло не привести к включению их в мировые политико-экономические отношения раннего средневековья, в первую очередь, с окружающим миром - Китаем, Ираном и Византией. В международных отношениях того времени одной из главных задач была борьба за контроль над маршрутами и узловыми пунктами Шелкового пути. Возникновение оседлости в Жетысу/Семи- 


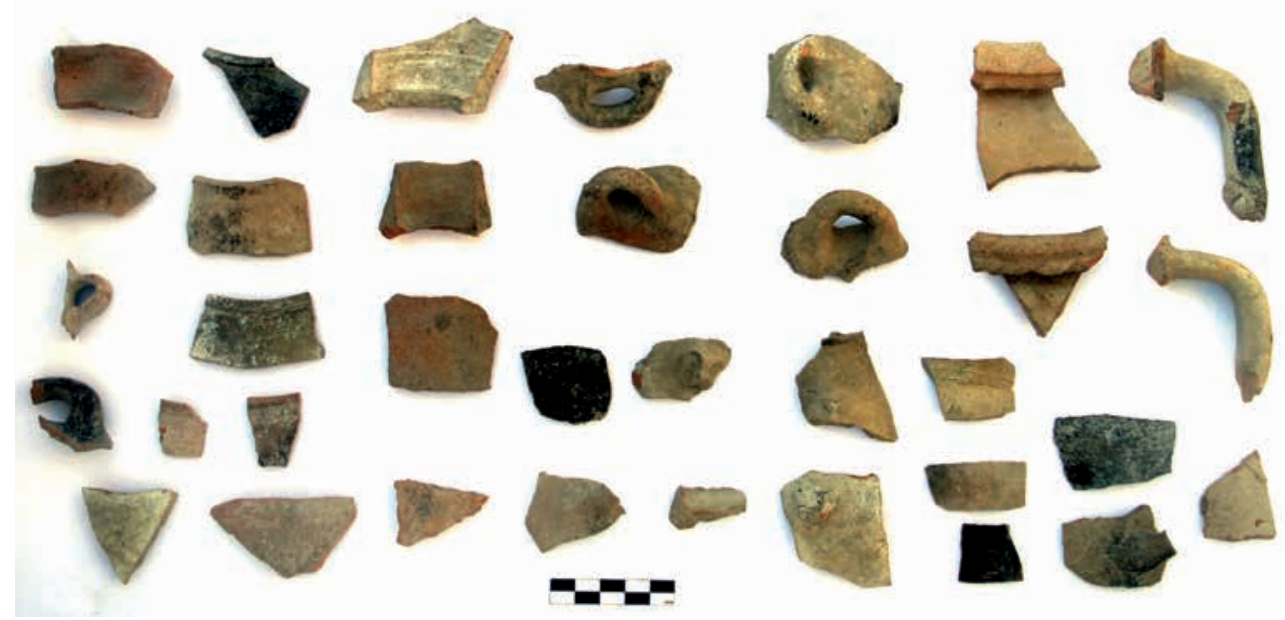

Рис. 10. Фрагменты керамических сосудов

Fig. 10. Fragments of ceramic vessels

речье относят к VII в. н.э., так называемому тюрко-согдийскому периоду. В. В. Бартольд предполагал, что образование северной ветки Великого шелкового пути связанно с возникновением в VI в. новой кочевой империи тюрков и возникшими в Фергане в VII в. смутами, продлившимися несколько десятилетий. «Минуя Фергану и Кашгар, путешественники отправлялись из Самарканда на северовосток, через Ташкент и Аулие-Ата в Семиречье к берегам Чу...» [Бартольд, 1963, с. 31]. Опираясь на сведения Сюань Цзяня о средневековой стране Сули, В. В. Бартольд предполагает, что развитие городской жизни в Средней Азии и Казахстане было связано с колонизаторской деятельностью согдийцев как в древности, так и в эпоху Кокандского ханства [Бартольд, 1927, с. 3-20]. По мнению исследователей, в VII в. происходила интенсивная согдийская колонизация в долинах рек Талас, Чу/Шу и Или/ Иле, которая привела к созданию десятков городов и укрепленных поселков [Кляшторный, 1992, с. 94-98].
А. Н. Бернштам уделяет большое значение влиянию согдийской культуры на культуру населения Жетысу. «Культура согдийских переселенцев, обнаруживаемая в укрепленных домах согдийских колоний ... типична своей керамикой. Если для глиняной посуды кочевников - саков, усуней, тюрок - характерно отсутствие на ней орнамента, для согдийской керамики весьма характерен крупномасштабный резной, лепной и желобчатый (вдавленный) орнамент различного типа (жгут, треугольник, резной зигзагообразный и т.д.)» [Бернштам, 1949, с. 366]. А. Н. Бернштам не давал точной датировки началу культурной экспансии согдийцев. «Городища Семиречья в нижних слоях содержат инвентарь согдийского происхождения.... Точной датировки для находок из нижних слоев семиреченских городищ пока еще у нас нет» [Бернштам, 1940, с. 55]. Однако полное отсутствие терракот и кувшинов с налепами, дастарханов на городище Рахат не позволяют с полной уверенностью 
Тулегенов Т.Ж., Чекин А.Г., Құрбандлі Ж. Археологические раскопки городища Рахат...

говорить именно о согдийском его происхождении.

Остановимся подробнее на керамике, найденной на вскрытых площадях городища Рахат (условно назовем их поселением). По большинству признаков она относится к первому хронологическому признаку керамики Северо-Восточного Жетысу, который выделил К. М. Байпаков, датируется VIII - началом X в. н.э. «...Лепная грубая и кухонная, изготовленная на ручном круге с большой примесью дресвы. Поливная керамика отсутствует. Большинство посуды в обломках. Археологически целых форм мало» [Байпаков и др., 2002, с. 73]. Керамика с поселения Рахат представлена в большинстве своем фрагментами венчиков и ручек котлов, фрагментами водоносов, найдены фрагменты двух хумов, светильник и большое количество фрагментированной керамики горшков без ручек. С определенной долей уверенности можно утверждать, что поселение Рахат является одновременным городищу Талхиз и входит в его периферию. Большой интерес представляют печи тандырного типа, которые являются своего рода маркером поселенческой инфраструктуры и датирующим материалом. А. Н. Бернштам называет их неизменными спутниками жилищ, начиная с IX в. [Бернштам, 1949, c. 377]. Таким образом, предварительная датировка вскрытых площадей городища Рахат укладывается в VIII-X вв.

\section{Bblвod}

Масштаб начатых работ на поселении пока не позволяет отнести его к какому либо типу (городищеубежище, караван-сарай). Также пока неизвестно, является ли оно многослойным и точное время его образования. Однако надо заметить, что встречающиеся фрагменты сакской керамики говорят о существовании поселений на этом очень удобном для проживания месте с древнейших времен.

Дальнейшее более глубокое изучение археологических памятников оседлой культуры в Жетысу позволит реконструировать процессы взаимоотношений различных традиций, расширить базу доказательств того, что территория Казахстана была одним из центров историко-культурного синтеза, взаимодействие кочевого и оседлого населения привело к взаимообогащению культур. Именно в недрах такого симбиоза лежат многие достижения культуры народов Казахстана.

\section{ЛИТЕРАТУРА}

1. Байпаков К.М. Поселения саков и усуней на территории Жетысу и Алматы. Алматы: ИД «Сredo», 2008. 172 с.

2. Отчет о работах на могильнике Иссык и поселении Рахат за 2004 г. // Архив ИА КН МОН РК. Ф. 11, оп. 2, д. 2659, 18 л.

3. Байпаков К.М., Савельева Т.В., Чанг К. Средневековые города и поселения северо-восточного Жетысу. Алматы: Институт археологии им. А.Х. Маргулана, 2002. $208 \mathrm{c}$. $256 \mathrm{c}$

4. Бартольд В.В. История культурной жизни Туркестана. Л.: АН СССР, 1927.

5. Бартольд В.В. Общие работы по истории Средней Азии // Сочинения: в 9 т. М.: Восточная литература, 1963. Т. 2, кн. 1. 1024 с. 
6. Бернштам А.Н. Основные этапы истории культуры Семиречья и ТяньШаня // CA. 1949. T. IX. C. 337-384.

7. Бернштам А.Н. Согдийская колонизация Семиречья // КСИИМК. 1940. Вып. 6. С. 34-43.

8. Кляшторный С.Г., Султанов Т.И. Казахстан. Летопись трех тысячелетий. Алма-Ата: «Рауан», 1992. 374 с.

9. Мұхтарова Г.Р., Тулегенов Т.Ж., Құрбанәлі Ж., Дин Ян, Миау Ифей, Жау Хан Чин Рахат қалашығындағы 2017 жылы жүргізілген археологиялық ізденіс жұмыстарының кейбір қорытындылары // Электрондық ғылыми журналы «edu.ehistory.kz». 2018. № 2 (14). URL: http://edu.e-history.kz/ru/publications/view/837 (дата обращения 31.01.2020 г.).

\section{Сведения об авторах:}

Тулегенов Туралы Жаксылыкович - старший научный сотрудник, Государственный историко-культурный заповедник-музей «Иссык» (г. Есик, Казахстан); tulegenov1309@gmail.com

Чекин Алексей Геннадьевич - старший научный сотрудник, Государственный историко-культурный заповедник-музей «Иссык» (г. Есик, Казахстан); alexei.ch73@mail.ru

Құрбанәлі Жазира - руководитель отдела охраны и исследования городища Талгар, Государственный историко-культурный заповедник-музей «Иссык» (г. Есик, Казахстан); zhazi1981@inbox.ru

\section{9 ЖЫЛҒЫ ДАЛАЛЫҚ МАУСЫМ КЕЗІНДЕГІ РАХАТ ҚАЛА-ЖҰРТЫНДАҒЫ АРХЕОЛОГИЯЛЫҚ ҚАЗБА ЖҰМЫСТАРЫ}

\section{Т. Ж. Тулегенов, А. Г. Чекин, Ж. Құрбанәлі}

Мақалада 2019 жылғы ғылыми-зерттеу жобасы аясында жүргізілген далалық зерттеулердің нәтижелері, Жетісу халқының материалдық мәдениетінің семиозисін археологиялық тұрғыдан зерттеу: сақ дәуірінен XIII ғасырға дейінгі Рахат археологиялық кешенінің материалдық ескерткіштерін одан әрі мәдени-ағартушылық, музейлік және туристік мақсаттарда, басқа да тарихи ошақ көзі ретінде ғылыми айналымға енгізу жұмыстары қарастырылған. Алдын ала жасалған тұжырым бойынша, Рахат археологиялық кешені тас дәуірінен бастап (төменгі палеолит дәуірінің тұрағы табылған) этнографиялық кезеңге дейінгі (XIX ғасырдағы су диірмендері мен жертөлелері) тұрғындарының тарихынан сыр шертетін бірегей орын екендігін көруге болады. Қалашықты одан әрі зерттеу жұмысы Есік шағын ауданындағы ортағасырлық қаланың экономикасы мен мәдениеті туралы толық ақпарат береді. Осылайша «Есік» қорық-музейі жүргізген Рахат шатқалындағы археологиялық зерттеу жұмыстары зерттелетін тарихи-мәдени мұра нысандарының ерекше бірегейлігін көрсетеді. Жетісу өңірі өзіндік тартымды геологиялық, морфологиялық және климаттық жағдайларына байланысты жартылай отырықшы тұрғындардың көне дәуірден ұзақ уақыт бойы бұл өңірді қоныстануынан тарихи дәуірлер сабақтастығын байқауға болады.

Түйін сөздер: археология, Жетісу, «Есік» қорық-музейі, «Алтын адам» ассоциациясы, Рахат қалашығы, керамика, ортағасыр, археологиялық барлау, стратиграфия, мәдени қабат

\section{ARCHAEOLOGICAL EXCAVATIONS of the RAKHAT SETTLEMENT in the 2019 FIELD SEASON}

\section{T. J. Tulegenov, A. G. Chekin, J. Kurbanali}

The article presents the results of field research in 2019, conducted within the framework of the scientific research project archaeological study of the semiosis of material culture of the population of Jetysu: from the Saks era to the XIII century, on the materials of 
monuments that are part of the archaeological complex Rakhat for introduction into scientific circulation and further use for cultural, educational, museum and tourist purposes. According to the preliminary conclusion, we can say that the Rakhat archaeological complex is a unique place where we can trace the history of the inhabitants of the region from the Stone Age (the upper Paleolithic site was found) to the ethnographic period (mills and dugouts of the XIX century). Further study of the settlement will give a more complete picture of the life and economy of the medieval city in the Issyk microregion. Thus, the archaeological research carried out by the "Issyk" reserve-museum in the Rakhat gorge indicates the exceptional uniqueness of the studied objects of historical and cultural heritage, which can be used to trace the continuity of historical epochs over tens of thousands of years, which tells us that the Jetysu region was inhabited and settled by people for a huge period of time due to its attractive geological, morphological and climatic conditions.

Keywords: archaeology, Jetysu, the reserve-museum "Issyk", association "Altyn Adam", the ancient city of Rakhat, ceramics, medieval, excavation, archaeological exploration, stratigraphy, cultural layer

\section{REFERENCES}

1. Baipakov, K. M. 2008. Poseleniya sakov i usunei na territorii Jetysu i Almaty (Settlements of Sakas and Usuns Jetysu and Almaty). Almaty: Id «Credo» (in Russian).

2. In Arkhiv Instituta arheologii (Archive of the A.Kh. Margulan Institute of Archaeology), f. 11, op. 2, d. 2659, 18p. (in Russian).

3. Baipakov, K. M., Savelyeva, T. V., Chang, K. 2002. Srednevekovye goroda $i$ poseleniya severo-vostochnogo Jetysu (Medieval towns and sities of north-eastern Jetisu). Almaty: A.Kh. Margulan Institute of Archeology Publ. (in Russian).

4. Bartold, V. V. 1927. Istoriya kulturnoi zhizni Turkestana (The history of the cultural life of Turkestan). Leningrad: USSR Academy of Sciences Publ. (in Russian).

5. Bartold, V. V. 1963. Obshie raboty po istorii Srednei Azii (General works on the history of Central Asia). Sochineniya: v 9 t. T. 2, kn. 1. Moscow: "Vostochnaya literature" Publ. (in Russian).

6. Bernchtam, A. N. 1940. In Kratkie soobshcheniya Instituta istorii materialnoy kultury (Brief Communications from the Institute of the History of Material Culture), 6 , 34-43 (in Russian).

7. Bernshtam, A. N. 1949. In Sovetskaya arheologiya (Soviet archeology), IX, 337-384 (in Russian).

8. Klyashtornyi, S. G., Sultanov, T. I. 1992. Kazahstan. Letopis trekh tysyacheletiy (Chronicle of three millennia). Alma-Ata: "Rauan" (in Russian).

9. Mukhtarova, G. R., Tulegenov, T. J., Qurbanali, J., Din Yan, MiauIfei, Jau Han Chin. 2018. In «edu.ehistory.kz», 2 (14). URL: http://edu.e-history.kz/ru/publications/ view/837 (in Kazakh).

About the Authors:

Tulegenov Turaly J. Senior Researcher, State historical and cultural reserve-museum "Issyk" (Esik, Kazakhstan); tulegenov1309@gmail.com

Chekin Aleksey G. Senior Researcher, State historical and cultural reserve-museum "Issyk" (Esik, Kazakhstan); alexei.ch73@mail.ru

Kurbanali Jazira. Head Talgar settlement protection and research department, Issyk State Historical and Cultural Reserve-Museum (Esik, Kazakhstan); zhazi1981@inbox.ru

Мүдделер қақтығысы туралы ақпаратты ашу. Авторлар мүдделер қақтығысының жоқтығын мәлімдейді. / Раскрытие информации о конфликте интересов. Авторы заявляют об отсутствии конфликта интересов. / Disclosure of conflict of interest information. The authors claims no conflict of interest.

Мақала туралы ақпарат / Информация о статье / Information about the article. Редакцияға түсті / Поступила в редакцию / Entered the editorial office: 31.03.2020. Рецензенттер мақұлдаған / Одобрено рецензентами / Approved by reviewers: 14.03.2020 Жариялауға қабылданды / Принята к публикации / Accepted for publication: 28.04.2019. 